A large number of papers were read on the mornings of the two following days. As a special feature of the papers and presidential addresses was their bearing on South African questions, exceptional interest was taken in the sectional proceedings.

The following excursions were made on August I 7 :-(I) botanical excursion to the Kloof Nek; (2) visit to Groote Schuur for lady members of the British Association by invitation of the Loyal Women's Guild of South Africa; (3) visit to the Central Electric Station of the Cape Town Corporation. In the evening a lecture was given in the City Hall before a crowded audience on "W. J. Burchell's Discoveries in South Africa," by Prof. E. B. Poulton, F.R.S.

The afternoon of August 18 was devoted to excursions; and a reception was held by Sir David and Lady Gill at the Royal Observatory. In the evening a lecture was given in the City Hall on "Some Surface Actions of Fluids" by Mr. C. V. Boys, F.R.S.

Saturday, August 19, was devoted entirely to the following excursions:--(I) geological excursion; (2) Wellington; (3) De Beers Explosive Works; (4) Houts Bay; (5) Groot Constantia and Tokai (6) Robben Island; (7) Stellenbosch; (8) Admiralty Works at Simons Town and Marine Station at St. James; (9) Table Mountain via. Saddle Face; (Io) Table Mountain viâ Wynberg; (I I) Table Mountain via Kasteel Poort.

Dr. W. Flint (librarian to the Houses of Parliament), who accompanied the association throughout its entire journey, has undertaken to send NATURE some account of the Natal, Johannesburg, and Rhodesian proceedings. The following notes are from a letter just received, with the promise of a further instalment by the next mail.

On the termination of the meeting in Cape Town the main body of the members of the association proceeded to Durban in the Union Castle steamers Saxon and Durham Castle. The former steamer left the docks on Friday evening, August 18 , and its passengers were debarred from taking part in the numerous Cape Town excursions which had been arranged for the Saturday. The Saxon passengers had, however, the advantage of brief visits to Port Elizabeth and East London, at each of which ports of call a few hours were spent, and hospitality was tendered by the mayor and citizens. The Durham Castle proceeded direct to Durban, and, making a record passage, arrived a little in advance of the mail steamer. A party of some thirty persons elected to proceed to Durban overland in one of the trains provided by the Cape Government, which was proceeding to Durban to meet the steamers. A special geological excursion through the Hex River Pass on to the Karroo captured a few enthusiasts, who, under the guidance of Mr. A. W. Rogers, of the Cape Geological Survey, spent a few days which proved to be of great interest. These members necessarily had to deprive themselves of the pleasure of the Natal section of the tour. The trip overland to Durban, which occupied four nights and three days, was unanimously voted a great success, and as several of the passengers are proceeding to England by Beira and the east coast, the opportunity of seeing the Karroo was much appreciated.

The two days spent in Durban and the neighbourhood were very fully occupied, the hospitable ideas of the mayor and his numerous helpers having provided a very attractive programme. Tuesday morning, August 22, was occupied in settling down and taking the bearings of the town, and early in the afternoon a public welcome was tendered by the mayor; Mr. Henwood, to which Prof. Darwin reNC, 1875 , vOL. 72 ] sponded. A garden party generously given by Sir Benjamin Greenacre, for which very elaborate preparations had been made, was partly spoiled by a heavy thunderstorm, but large numbers braved the downpour and were rewarded by seeing a few of the glories of the Berea.

Two lectures were given in Durban to very large audiences. Mr. Douglas W. Freshfield discoursed on "Mountains-the Highest Himalaya," and Prof. W. A. Herdman on "Marine Biology."

The second day in Durban was occupied chiefly with excursions. Perhaps the first place was taken by the entertainment provided by the Hon. Marshall Campbell at the Mount Edgecombe Sugar Estate. The contrast afforded by a Zulu war dance and a demonstration by Christian native girls was an object lesson which many were glad to have seen.

The excursion to Umkomaas was scarcely less enjoyed, the romantic subtropical scenery being a revelation to many of those who were privileged to be present. The botanists especially seemed to revel. in the opportunity, the wealth of Strelitzias in their native habitat being particularly attractive.

On Thursday morning, August 24, the whole party left in four trains, to be known henceforth as $\mathrm{A}, \mathrm{B}$, $\mathrm{C}$, and $\mathrm{D}$ trains, and arrived about mid-day in Maritzburg. The journey is one of the most attractive in South Africa, passing in its earlier stages through sugar, banana, and pine-apple plantations, and ascending rapidly to the Botha Hill heights, from which views of singular extensiveness and beauty are obtained. On reaching Maritzburg admirably complete arrangements were found to have been made, and members found themselves welcomed with great cordiality by Mr. A. W. Kershaw, the Mayor, and a host of willing citizens who had thrown themselves with great zeal into their task.

His Excellency Colonel Sir H. E. McCallum held a garden party at Government House which was a very successful function, and in the evening the Town Hall was thronged when His Excellency and the Mayor gave addresses of welcome. Colonel Bruce followed with a lecture on "Sleeping Sickness" which created great interest.

On the following day there were visits to the Government experimental farm and the Government laboratory, but it is to be feared that these were somewhat overshadowed by the Kafir dance and wedding which took place at Henley. The wedding was that of a young hereditary chief, and was preceded by the various dances and ceremonies customary on such an occasion. Never, probably, were so many photographs taken on a single day in Natal. The cameras were legion, and some of the photographers were not content with less than two or three dozen of pictures.

In the evening the young Natalian member of the official party, Mr. H. D. Ferrar, by special request, gave a lecture on "Antarctic Regions," he having been a member of the Discovery Antarctic Expedition.

Both in Durban and Maritzburg all members of the association had free use of the municipal trams, and nothing was left undone to ensure the comfort and enjoyment of the visitors, who in their turn were loud in their praises of the reception accorded.

\section{TWO REPORTS OF THE FRENCH GLACIER COMMISSION.}

AECORD of observations on snowfall and avalanches undertaken by the Forestry Department of Savoy during Igo4 on the south-west flank of Mont Blanc is contained in a paper entitled " Observations sur 1'Enneigement et sur les Chutes d'Avalanches," issued by the Commission française des Glaciers (Paris: Club Alpin français). The 
vaper is a continuation by M. Mougin of his report of June, I903, and deals with the results obtained from the seven instruments placed at appointed stations between the village of Houches and the Aiguille du Goûter. Unfortunately, the snow-gauge placed on the Aiguille du Goûter was destroyed by a party of young students from Geneva who attempted the ascent of Mont Blanc without guides in 1902 . On the Tête-Rousse, again, the instrument was found completely empty; fortunately, however, the platform snow-recorder, placed on the glacier, enabled an estimate of the snowfall to be made.

The general results derived from the records of these seven stations show that between Iooo metres and 3200 metres the snowfall increases with altitude, but the results are not altogether satisfactory. Thus the record at 2 I00 metres gives a fall equivalent to $0.3 \mathrm{r} 94 \mathrm{~mm}$. of water only, whereas the stations above and below show falls of $\mathrm{I} .848 \mathrm{~mm}$. and $0.49 \mathrm{I} \mathrm{mm}$. respectively.

Even if the upper station is excessive, the station above at 2850 metres at the Pierre-Rondestill shows an increase, being $0.446 \mathrm{I} \mathrm{mm}$; it is possible, therefore, that the mouth of the instrument has become blocked by a film of verglas. With regard to the large fall recorded at $255^{\circ}$ metres, it is possible that here we have the altitude at which the greatest precipitation takes place. The loss of the instrument at the summit of the Aiguille du Goûter is all the more to be regretted on this account, as it would undoubtedly have thrown light on this point, and it is to be hoped that the instrument may speedily be replaced

The report gives a detailed description of the instruments used. These consisted of horizontal boards placed one metre above the ground, and also of Vallot's snow-gauges of a modified design.

Comparative experiments were made during the winter at Chambéry between the official rain-gauge, the Vallot tubes, and the snow-table. The results are expressed in tables and by curves. No useful comparisons could be made between the rain-gauge and the Vallot tubes, but the results obtained with the latter instrument are compared with those obtained with the snow-table, and are expressed both in depth of snow and amount of water melted. The small number of snowstorms during the winter of I902-3 was also unfavourable to any definite conclusion being arrived at; further experiments are required.

The report ends with tables showing the snowfall and number of avalanches which fell in Savoy during 1902, also the damage done to forests, roads, and water-courses, and accidents to men and animals.

Another report received from the Commission française des Glaciers deals with the observations by M. Paul Girardin on the glaciers of Maurienne, Vanoise, and Tarentaise during August and September, 1903 , and also with the glaciers of the massif of La Vanois in 1903, by J. A. Favre (Extrait de 1'Annuaire du Club Alpin français, vol. xxx., I903). M. Girardin arrives at the conclusion that these glaciers are retreating, the amount varying in different glaciers and even in different lobes of the same glacier. The general law is, therefore, complicated by local shade, \&c. Retreat is most marked where surface moraines are absent, while those covered thickly with débris are more stationary. The rate of retreat has, however, diminished during the last ten years.

In the massif of the Vanoise we find the same story. Glaciers like the Grands-Couloirs, Pelvoz, \&c., are all losing in thickness. In the case of the Pelvoz a new medial moraine has appeared owing to the marked ablation, while a glacier marked on the map north of the $\mathrm{Col}$ d'Aussois has completely disappeared.

NO. I 875 , VOL. 72$]$
E. J. G.

\section{INTERNATIONAL METEOROLOGICAL CONFERENCE AT INNSBRUCK.}

\section{Second and Third Meetings. ${ }^{1}$}

A MONG the various points brought under notice, $A$ the president, Dr. Pernter, stated that $M$. Violle wished that his proposals made to the meeting at Southport on the question of solar radiation should be discussed. After considerable deliberation, it was resolved that the principal observatories should be requested to make observations of solar and terrestrial radiation. Measurements should be made daily, those of solar radiation at $\mathrm{I} \mathrm{rh}$. a.m. or from $\mathrm{IIh}$. a.m. to Ih. p.m., and those of terrestrial radiation at roh. p.m. or from Ioh. p.m. to I2h. p.m. The apparatus used should be exclusively Angström's compensation actinometer.

Upon the subject of excessive rainfall, Dr. Landa, of the k.k. hydrographisches Central-Bureau (Vienna), proposed (I) that meteorological offices should be invited to inquire into the causes of origin of cases of excessively heavy rainfall over large areas, including those which have already occurred, and any that may occur in future, in the districts under their supervision, and to publish the results of their investigations, and (2) that it should be recognised as useful to investigate the historical documents of various countries for particulars of abnormal meteorological occurrences, such as floods, droughts, very severe winters, \&c., and to classify and publish the results of their researches.

The classification of meteorological stations, according to the nature of the work carried out, was referred to the International Meteorological Committee, as was also the definition of such phenomena as hoarfrost, silver-thaw, glazed frost, \&c.

On the important question of long series of homogeneous observations, necessary for the study of secular variations, the conference adopted Dr. Hellmann's proposal that central meteorological offices should establish in their respective organisations one or more secular stations, according to the extent of the country, and should carry on the observations as uniformly and continuously as possible. At the same time, the conference expressed the hope that old series of observations might be critically discussed and published.

On the proposal of M. Rosenthal, the conference requested General Rykatcheff to undertake, on the part of the Central Physical Observatory, St. Petersburg, the publication of a summary of the results of observations made during the last century. Dr. Hellmann was requested to assist in the preparation of this useful work.

Prof. von Bezold raised the question of the status of the conferences of directors, and of the International Meteorological Committee; he thought they should maintain an official character, so far as possible, and that the number of meetings should be as few as practicable. After considerable discussion, a proposal by Dr. Hellmann was adopted, viz. that the conference should request the International Meteorological Committee to draw up a standing order relating to the International Meteorological Organisation, at the same time taking note of the historical development of the committee. This rule, dealing with conferences of directors, the international committee, and the subcommittees, should be submitted to the next conference of directors for discussion.

M. Froc made a communication respecting the organisation of the meteorological service of the

1 An account of the opening meeting appeared in NATURE of Septem 2I (p. 510). 